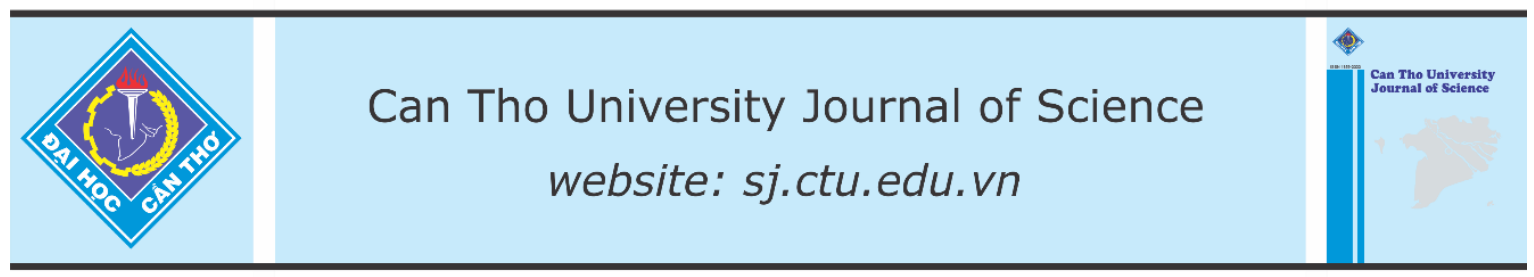

DOI: $10.22144 /$ ctu.jen.2021.012

\title{
Effects of temperature on growth performance, survival rate, digestive enzyme activities and physiological parameters of striped snakehead (Channa striata) at fry stage
}

\author{
Do Thi Thanh Huong ${ }^{1 *}$, Nguyen Thi Kim $\mathrm{Ha}^{1}$, Nguyen Tinh $\mathrm{Em}^{1}$, Tang Minh $\mathrm{Ky}^{2}$, \\ Yasuaki Takagi ${ }^{3}$ and Nguyen Thanh Phuong ${ }^{1}$ \\ ${ }^{1}$ College of Aquaculture and Fisheries, Can Tho University, Viet Nam \\ ${ }^{2}$ Can Tho City Fisheries Agency, Can Tho City, Viet Nam \\ ${ }^{3}$ Hokkaido University, Japan \\ *Correspondence: Do Thi Thanh Huong (email: dtthuong@ctu.edu.vn)
}

\section{Article info.}

Received 22 Feb 2021

Revised 04 May 2021

Accepted 04 Jun 2021

\section{Keywords}

Channa striata, digestive enzyme, growth, physiological responses, temperature

\begin{abstract}
The effects of temperature on growth performance, survival rate, digestive enzymatic activities, and physiological responses of striped snakehead (Channa striata) at fry stage were evaluated. The study consisted of two trials including (1) determination of temperature threshold and (2) effects of different temperatures $\left(24^{\circ} \mathrm{C}, 27^{\circ} \mathrm{C}\right.$ (control), $30^{\circ} \mathrm{C}, 33^{\circ} \mathrm{C}$ and $36^{\circ} \mathrm{C}$ ) on growth performance, survival rate, digestive enzyme activities and physiological parameters of striped snakehead fry stage for 90 days. The growth experiment was conducted in 500-L tank (250-L water) with triplicates. The stocking density was 300 individuals per tank. Striped snakehead at fry stage showed a high tolerance to temperature ranging from 10 to $40^{\circ} \mathrm{C}$. After 90 days, fish reared in $30^{\circ} \mathrm{C}$ performed the greatest weight and survival rate $(13.1 \pm 3.12 \mathrm{~g} /$ fish and $15.5 \pm 4.63 \%$, respectively). The number of red blood cells and hemoglobin concentrations increased with the increase in temperature. It was discovered that different temperatures (from 27 to $36^{\circ} \mathrm{C}$ ) did not significantly influence the number of white blood cells, osmolality, and ion concentration of fish. Glucose and cortisol concentrations increased with temperature rises and peaked in fish reared at $36{ }^{\circ} \mathrm{C}$, while temperatures of $30^{\circ} \mathrm{C}$ and $33^{\circ} \mathrm{C}$ showed higher digestive enzyme activities. It proves that $30^{\circ} \mathrm{C}$ is the optimal level for striped snakehead fry rearing.
\end{abstract}

\section{INTRODUCTION}

Striped snakehead (Channa striata) is popularly distributed in Vietnam and several countries in Asia such as Bangladesh, India, Pakistan, Sri Lanka, south of China, Thailand, and Vietnam (Talwar \& Jhingran, 1991). In nature, striped snakehead can be found in many types of water bodies including ponds, streams, and rivers, preferring stagnant and muddy water of plains and swamps. This species was also reported to be able to tolerate slightly brackish water (Talwar \& Jhingran, 1991) and high temperature above $30^{\circ} \mathrm{C}$ (Long et al., 2017). In Vietnam, striped snakehead has been one of the species contributing to the increased national freshwater aquaculture production and popularly farmed in the Mekong Delta. The total production has increased rapidly from $15,958 \mathrm{t}$ in 2006 to $62,906 \mathrm{t}$ in 2018 and was planned to scale up to $104,662 \mathrm{t}$ in 2020 
(compiled by Hien, 2019). However, the aquaculture industry has been predicted to be greatly impacted by climate change related risk factors such as salinity, temperature, and $\mathrm{CO}_{2}$ (Seggel and De Young, 2016). Intergovernmental Panel on Climate Change (IPCC, 2018) revealed that the average temperature of the Earth surface and ocean was increased $0.87^{\circ} \mathrm{C}$ (from 0.75 to $0.99^{\circ} \mathrm{C}$ ); and it will be warmer around $3-4^{\circ} \mathrm{C}$ than the average one of Earth surface. The Mekong Delta of Vietnam, the biggest aquaculture area in Vietnam, is projected as one of three deltas in the world to be heavily affected by climate change (IPCC, 2007). The average temperature in Vietnam is currently $27^{\circ} \mathrm{C}$ (Gasparrini et al., 2017) that is predicted to increase to $33^{\circ} \mathrm{C}$ in the $21^{\text {st }}$ century (IPCC, 2014). As a poikilothermic vertebrate, fish has been reported to be influenced by water temperature, dissolved oxygen concentration (DO) and photoperiod on feed consumption, metabolic rate, energetic cost, and growth (Brett, 1979; Elliott, 1982; Dutta, 1994; Bhikajee \& Gobin., 1998). In Channa striata, a previous study on the fingerling stage under different temperatures indicated that temperature of $31^{\circ} \mathrm{C}$ reported the highest growth rate with a significantly reduced food conversion rate, whereas the growth performance tended to decrease at $34^{\circ} \mathrm{C}$ (Chinh, 2014). Fish at fry stage is sensitive with environmental changes. However, the growth and physiological responses of striped snakehead fry exposed to temperature changes have not been documented in details. Therefore, it appears to be necessary to study on the effects of temperature on physiological parameters, digestive enzymatic activities, and growth performance of snakehead from fry to fingerling stage. The main objective of this study was to elucidate the growth and physiological responses of larval snakehead to different temperatures.

\section{MATERIALS AND METHODS}

\subsection{Animals and experimental conditions}

Fertilized striped snakehead eggs were obtained from a fish hatchery in Can Tho city. Eggs were then held in a $1-\mathrm{m}^{3}$ composite tank in normal condition (temperature $27-28^{\circ} \mathrm{C}$, oxygen $5-6 \mathrm{mg} / \mathrm{L}$ and $\mathrm{pH}$ 78) with approximate density of $150 \mathrm{eggs} / \mathrm{L}$ until hatching in the wet laboratory of the College of Aquaculture and Fisheries, Can Tho University. After 24-hour post-hatching, the actively swimming fries were collected and transferred into rearing tanks.

\subsection{Experimental designs}

\subsubsection{Identifying thermal tolerance thresholds of striped snakehead at fry stage}

\section{Upper temperature threshold}

The experiment was set up in 35-L round plastic containers (containing 20-L water). Stocking density was 20 fries per container with four replicates. The initial temperature was around $27-28^{\circ} \mathrm{C}$, then increased in a stepwise, $1^{\circ} \mathrm{C}$ per 3 hours by heater (EHEIM professional 4+ 350T - Germany) and the temperature of water were increased until the mortality was around $50 \%$. This level was considered as the upper-temperature threshold.

\section{Lower temperature threshold}

The experiment was designed as described above (upper temperature threshold) and conducted in an air-conditioned room. The initial temperature was around $27-28^{\circ} \mathrm{C}$ and decreased $1^{\circ} \mathrm{C}$ per 3 hours using the plastic ice bags and cooler (TECO SeaChill TR10) to maintain the temperature during 3 hours before decreasing temperature to the lower level. The experiment was stopped as the mortality was around $50 \%$. This level was considered as the lowertemperature threshold.

\subsubsection{Investigating effects of temperature on growth, survival, digestive enzymatic activities and physiological parameters of fish at fry stage}

In Vietnam, the average temperature is currently around $27^{\circ} \mathrm{C}$ (Gasparrini et al., 2017), which was predicted to increase up to $33^{\circ} \mathrm{C}$ in the $21^{\text {st }}$ century (IPCC, 2014). This estimated temperature was combined with the results of upper and lower temperature threshold experiments $\left(40^{\circ} \mathrm{C}\right.$ and $10^{\circ} \mathrm{C}$, respectively) for choosing five temperature levels including $24^{\circ} \mathrm{C}, 27^{\circ} \mathrm{C}$ (control), $30^{\circ} \mathrm{C}, 33^{\circ} \mathrm{C}$ and $36^{\circ} \mathrm{C}$ for this study. The experiment was carried out in $500-\mathrm{L}$ round composite tanks $(111 \mathrm{~cm} \times 75 \mathrm{~cm})$ for a period of 90 days from the day that all treatments reached the experimental temperature levels. Actively swimming fry (24-hour post-hatching) was randomly exposed to the five different temperatures with the density of 300 ind./250-L water. Three replicates were applied for each temperature. For $24^{\circ} \mathrm{C}$ treatment, the temperature was decreased in a stepwise of $1^{\circ} \mathrm{C}$ per 12 hours and maintained at the target level by cooler (TECO SeaChill TR10), while the higher temperatures were increased $1^{\circ} \mathrm{C}$ per 12 hours by 
heaters starting from ambient temperature $27^{\circ} \mathrm{C}$. The treatments with higher temperature levels were elevated before the lower ones to ensure all treatments reaching the desirable temperatures at the same time.

During the experiment, fish were fed to satiation, four times daily at 7:00, 11:00, 14:00, and 18:00 o' clock. After completely consuming their yolk sac (2day post-hatching), the fish were fed with Moina (1620 ind./mL). Moina were used to feed the fish until day $10^{\text {th }}$. From $11^{\text {th }}$ day to $30^{\text {th }}$ day; the fish were fed with Moina and commercial powder feed (42\% of crude protein); the density of Moina was reduced gradually from $10-16$ ind./mL to $5-10$ ind. $/ \mathrm{mL}$ and then $0-5$ ind. $/ \mathrm{mL}$, while the percentage of commercial feed was increased gradually until the $30^{\text {th }}$ day (Huong et al., 2020). From the $30^{\text {th }}$ day to the $60^{\text {th }}$ day, fish were completely fed commercial powder feed ( $42 \%$ of crude protein) with a feeding rate of $15 \%-25 \%$ body weight. From the $60^{\text {th }}$ day onwards, fish were fed with floating commercial pellets ( $40 \%$ of crude protein, $\mathrm{d}=0.8 \mathrm{~mm}$ ) to satiation, uneaten pellets were collected 30- minute post-feeding to prevent water pollution. The mortality was recorded for determining the survival rate. Water in tanks was refreshed every three days in a ratio of $30 \%$ of total volume in combination with bottom cleaning.

\section{Water quality parameters}

The experiment was conducted indoor to keep the environmental parameters stable. Water temperatures of experimental tanks were controlled at desirable levels throughout the rearing period. $\mathrm{pH}$ (WTW Multi 3510 IDS) was checked daily and fluctuated from 7.55 to 7.80 . Levels of nitrite and total ammonia nitrogen were weekly recorded using Griess llosvay and Diazonium and Indophenol blue methods and fluctuated from 0.19 to 0.52 and from 0.18 to $0.50 \mathrm{mg} / \mathrm{L}$, respectively. These parameters were kept within accepted ranges for aquatic species (Boyd, 1990).

\section{Sample collection}

\section{a. Survival rate and growth performance}

Growth parameters were calculated based on fish weight. Initial fish weight was determined by weighing three samples of 30 individuals using analytical balance (Sartorius, CP2245, accuracy of $0.0001 \mathrm{~g}$ ). Every 30 days, the individual fish each tank were weighed. Additionally, the number of remaining fish in each tank were recorded for determining survival rates at different samplings. $\begin{aligned} & \begin{array}{l}\text { Survival } \quad \text { rate } \\ \text { Number of survival fish at the end of experiment }\end{array} \\ & \text { Numbers of initial fish }\end{aligned} 100=$

Daily weight gain $(\mathrm{DWG}, \mathrm{g} / \mathrm{day})=\frac{W f-W i}{t}$

Specific growth rate (SGR, \%/day) = $\frac{\mathrm{Ln}(\mathrm{Wf})-\mathrm{Ln}(\mathrm{Wi})}{\mathrm{t}} \times 100$

In which: Wi: the initial weight (g); Wf: the final weight (g); and t: the experimental time (day)

\section{b. Physiological responses}

Blood samplings were conducted at the end of the experiment. Three fish per tank were carefully captured by a hand-net, and an amount of approximately $0.3 \mathrm{~mL}$ of blood was immediately withdrawn from the caudal vein using a $1 \mathrm{~mL}$ pre-heparinized syringe. To minimize stress, the individuals' heads were covered with a cool moist towel (Snellgrove \& Alexander, 2011). The number of red blood cells (RBCs), white blood cells (WBCs), and hemoglobin concentration $(\mathrm{Hb})$ in the blood was quickly evaluated. Besides, the remaining blood samples were centrifuged at $6,000 \mathrm{rpm}$ for $6 \mathrm{~min}$ at $4^{\circ} \mathrm{C}$ to collect serum for analyzing glucose, cortisol, osmolality, sodium $\left(\mathrm{Na}^{+}\right)$and chloride ion $\left(\mathrm{Cl}^{-}\right)$concentrations.

The total RBCs count was determined manually in a 1:200 dilution of the blood sample in Natt-Herrick's solution as a diluent stain using a Neubauer haemacytometer (Natt \& Herrick, 1952). Hb (g/dL) was determined using the cyanohemoglobin method; a $10 \mu \mathrm{L}$ blood sample was mixed with $2.5 \mathrm{~mL}$ of Drabkin reagent (Hawk, 1965). Hb of samples were determined at $540 \mathrm{~nm}$ using a spectrophotometer (Cary 50 Conc). WBCs were determined according to the unified methods for hematological examination of fish (Hrubec et al., 2000). The plasma osmolality of fish was measured by using a Micro Osmometer (Advanced Instruments Model 3300, Advanced Instruments Inc, USA); $\mathrm{Cl}^{-}$was measured by a chloride titrator (Sherwood model 926S MK II Chloride analyzer, Sherwood Scientific Ltd., Cambridge, $\mathrm{UK}) ; \mathrm{Na}^{+}$was measured by a Flame Photometer 420 (Sherwood Scientific Ltd., Cambridge, UK). Glucose was analysed by following the method of Hugget and Nixon (1957). [Cortisol] was measured by Elisa kit (DRG Instruments $\mathrm{GmbH}-$ Germany).

\section{c. Enzymatic activity}

After the blood collection, the three sampled fish per tank were dissected on a glass plate placed on ice. Stomach and intestine were collected to analyze 
digestive enzymatic activities. Samples were thawed on ice and homogenated with the buffer $\mathrm{KH}_{2} \mathrm{PO}_{4} 20 \mathrm{mM}$ and $\mathrm{NaCl} 6 \mathrm{mM}, \mathrm{pH}$ 6.9. The mixture was centrifuged in $30 \mathrm{~min}$ at $4,200 \mathrm{rpm}$ and $4^{\circ} \mathrm{C}$ and then supernatant was collected and stored at $80^{\circ} \mathrm{C}$ for further analyses. Chymotrypsin and pepsin activities were performed by specific method of Worthington (1982), while trypsin and amylase were analyzed by the methods of Tseng et al. (1982) and Bernfeld (1951), respectively. Protein was determined by using Biorad protein assay. Specific activities are expressed as $\mathrm{U}$ mg protein ${ }^{-1} \mathrm{~min}^{-1}$.

\subsection{Statistical analysis}

All the data were subjected to statistical treatment involving standard deviation (stdev) and mean using Excel 2016. One-way analysis of variance (ANOVA) together with Duncan tests were used to test for significant differences (at a significant level of 0.05 ) by using SPSS 16.0.

\section{RESULTS}

\subsection{Temperature threshold}

The mortality occurred when the temperature in containers was reduced to $13^{\circ} \mathrm{C}$. Such a rate increased to $4 \%$ as the temperature reached the level of $12^{\circ} \mathrm{C}$. When the temperature dropped to $10^{\circ} \mathrm{C}$, the mortality rate increased to $52.5 \%$ from $20 \%$ recorded at $11^{\circ} \mathrm{C}$. In the upper temperature threshold experiment, the first dead fish $(2.5 \%)$ were monitored at $37^{\circ} \mathrm{C}$, and this rate increased to $5 \%$ at $38^{\circ} \mathrm{C}$. The mortality of fry was $18.8 \%$ at the temperature of $39^{\circ} \mathrm{C}$, then increased up to $52.5 \%$ as the temperature reached $40^{\circ} \mathrm{C}$. The results of two experiments showed that the temperature threshold range of striped snakehead fry was quite wide. The upper temperature threshold was up to $40^{\circ} \mathrm{C}$, while the lower temperature threshold was $10^{\circ} \mathrm{C}$.
Table 1. Average number and percentage of fry dead at the upper and lower temperature threshold experiments

\begin{tabular}{lrr}
\hline $\begin{array}{c}\text { Temper- } \\
\text { ature }\end{array}$ & $\begin{array}{c}\text { Average number of } \\
\text { fry dead/tank }\end{array}$ & $\begin{array}{c}\text { Mortality } \\
(\%)\end{array}$ \\
\hline Upper temperature threshold & \\
$37^{\circ} \mathrm{C}$ & 0.50 & 2.50 \\
$38^{\circ} \mathrm{C}$ & 1.00 & 5.00 \\
$39^{\circ} \mathrm{C}$ & 3.75 & 18.75 \\
$40^{\circ} \mathrm{C}$ & 10.5 & 52.5 \\
Lower temperature threshold & \\
$13^{\circ} \mathrm{C}$ & 0.5 & 2.5 \\
$12^{\circ} \mathrm{C}$ & 4.00 & 20.0 \\
$11^{\circ} \mathrm{C}$ & 4.00 & 20.0 \\
$10^{\circ} \mathrm{C}$ & 10.5 & 52.5 \\
\hline
\end{tabular}

Data presented as mean of four replicates.

\subsection{Effect of temperature on growth and physiological responses of fry stage after 90 days}

\section{a. Physiological parameters}

The size of fish $(1.20 \pm 0.34 \mathrm{~g} /$ fish $)$ in $24^{\circ} \mathrm{C}$ treatment was too small to collect blood for hematological parameter analysis. Therefore, the results of hematological parameter analysis in this study were for $27^{\circ} \mathrm{C}, 30^{\circ} \mathrm{C}, 33^{\circ} \mathrm{C}$ and $36^{\circ} \mathrm{C}$ treatments. The number of WBCs of fish was not significantly different among experimental temperatures. It is noted that the number of RBCs of fish increased with the temperature rises. The lowest RBCs were found in $27^{\circ} \mathrm{C}$ treatment $\left(2.61 \pm 0.66 \times 10^{6}\right.$ cell $\left./ \mathrm{mm}^{3}\right)$, which was significantly lower than 33 and $36^{\circ} \mathrm{C}$ treatments $\left(3.42 \pm 0.16 \times 10^{6}\right.$ and $3.78 \pm 0.06 \times 10^{6} \mathrm{cell} / \mathrm{mm}^{3}$, respectively). $\mathrm{Hb}$ markedly increased at $36^{\circ} \mathrm{C}$ $(13.0 \pm 1.39 \mathrm{~g} / 100 \mathrm{~mL})$ compared to $10.1 \pm 0.25 \mathrm{~g} / 100$ $\mathrm{mL}$ at $27^{\circ} \mathrm{C}$.

Table 3. Red blood cells (RBCs), white blood cells (WBCs) and hemoglobin concentration (Hb) of fish reared in different temperatures

\begin{tabular}{|c|c|c|c|}
\hline Treatment & RBCs $\left(\times 10^{6}\right.$ cell $\left./ \mathrm{mm}^{3}\right)$ & WBCs $\left(x^{3} 0^{3}\right.$ cell $\left./ \mathrm{mm}^{3}\right)$ & {$[\mathrm{Hb}](\mathrm{g} / 100 \mathrm{~mL})$} \\
\hline $27^{\circ} \mathrm{C}$ & $2.61 \pm 0.66^{\mathrm{a}}$ & $124 \pm 13.3^{\mathrm{a}}$ & $10.1 \pm 0.25^{\mathrm{a}}$ \\
\hline $30^{\circ} \mathrm{C}$ & $2.87 \pm 0.26^{\mathrm{ab}}$ & $101 \pm 10.9^{\mathrm{a}}$ & $11.3 \pm 1.15^{\mathrm{ab}}$ \\
\hline $33^{\circ} \mathrm{C}$ & $3.42 \pm 0.16^{\mathrm{bc}}$ & $121 \pm 9.6^{\mathrm{a}}$ & $11.8 \pm 1.17^{\mathrm{ab}}$ \\
\hline $36^{\circ} \mathrm{C}$ & $3.78 \pm 0.06^{\mathrm{c}}$ & $129 \pm 21.1^{\mathrm{a}}$ & $13.0 \pm 1.39^{c}$ \\
\hline
\end{tabular}

Data presented as mean \pm std. Values with different letters in the same column is significantly different $(p<0.05)$.

\section{b. Glucose and cortisol concentrations}

The glucose and cortisol increased with the temperature rise. The lowest values were recorded in $27^{\circ} \mathrm{C}$ treatment $(66.5 \pm 10.3 \mathrm{mg} / 100 \mathrm{~mL}$ and $258 \pm 21.7$ $\mathrm{ng} / \mathrm{mL}$, respectively), which were significantly lower than those of the $36^{\circ} \mathrm{C}$ treatment $(122 \pm 9.67$ $\mathrm{mg} / 100 \mathrm{~mL}$ and $386 \pm 31.4 \mathrm{ng} / \mathrm{mL}$, respectively) $(\mathrm{p}<0.05)$. However, it has been shown that there was no significant difference in cortisol and glucose 
concentrations among 27,30 and $33^{\circ} \mathrm{C}$ treatments (Table 4).

Table 4. Cortisol and glucose concentrations of snakehead fry observed under different temperatures

\begin{tabular}{lrr}
\hline Treatments & $\begin{array}{r}\text { Cortisol } \\
(\mathbf{n g} / \mathbf{m L})\end{array}$ & $\begin{array}{r}\text { Glucose } \\
(\mathbf{m g} / \mathbf{1 0 0} \mathbf{~ m L})\end{array}$ \\
\hline $27^{\circ} \mathrm{C}$ & $258 \pm 21.7^{\mathrm{a}}$ & $66.5 \pm 10.3^{\mathrm{a}}$ \\
$30^{\circ} \mathrm{C}$ & $269 \pm 26.9^{\mathrm{a}}$ & $77.1 \pm 6.46^{\mathrm{a}}$ \\
$33^{\circ} \mathrm{C}$ & $257 \pm 16.4^{\mathrm{a}}$ & $97.1 \pm 17.3^{\mathrm{ab}}$ \\
$36^{\circ} \mathrm{C}$ & $386 \pm 31.4^{\mathrm{b}}$ & $122 \pm 9.67^{\mathrm{b}}$ \\
\hline
\end{tabular}

Data presented as mean \pm std. Values with different letters in the same column is significantly different $(p<0.05)$.

\section{c. Osmolality, chloride and sodium ion concentrations}

The results showed that the osmolality and $\mathrm{Na}^{+}, \mathrm{Cl}^{-}$ were not significantly different among temperature levels ( $p>0.05)$. The osmolality of fish ranged between $290 \pm 0.76$ and $298 \pm 3.17 \mathrm{mOsm} / \mathrm{kg}$. $\mathrm{Na}^{+}$was from $136 \pm 0.77$ to $143 \pm 2.48 \mathrm{mmol} / \mathrm{L}$ and $\mathrm{Cl}^{-}$fluctuated from $101 \pm 1.04$ to $109 \pm 8.93 \mathrm{mmol} / \mathrm{L}$.

Table 5. Osmolality, chloride and sodium ion concentrations of fry stage after 90 days

\begin{tabular}{lrrr}
\hline Treatment & Osmolality $\mathbf{( m O s m} / \mathbf{k g})$ & $\mathbf{N a}^{+}(\mathbf{m m o l} / \mathbf{L})$ & $\mathbf{C l}^{-}(\mathbf{m m o l} / \mathbf{L})$ \\
\hline $27^{\circ} \mathrm{C}$ & $290 \pm 0.76^{\mathrm{a}}$ & $143 \pm 2.48^{\mathrm{a}}$ & $109 \pm 8.93^{\mathrm{a}}$ \\
$30^{\circ} \mathrm{C}$ & $298 \pm 3.17^{\mathrm{a}}$ & $136 \pm 0.77^{\mathrm{a}}$ & $101 \pm 1.04^{\mathrm{a}}$ \\
$33^{\circ} \mathrm{C}$ & $296 \pm 2.84^{\mathrm{a}}$ & $142 \pm 4.54^{\mathrm{a}}$ & $105 \pm 2.59^{\mathrm{a}}$ \\
$36^{\circ} \mathrm{C}$ & $292 \pm 2.05^{\mathrm{a}}$ & $142 \pm 1.84^{\mathrm{a}}$ & $104 \pm 3.44^{\mathrm{a}}$ \\
\hline
\end{tabular}

Data presented as mean \pm std. Values with different letters in the same column is significantly different $(p<0.05)$.

\section{d. Digestive enzymatic activities}

The digestive enzymatic activities of the fish at high temperature treatments 30,33 , and $36^{\circ} \mathrm{C}$ showed significantly higher than those of the treatments $24^{\circ} \mathrm{C}$. Specially, the amylase enzymatic activity in the intestine of fish increased with temperature rise while the trypsin, chymotrypsin, and pepsin enzyme activities increased as the temperature rose from 24 to $30^{\circ} \mathrm{C}$ and tended to decrease at the higher temperatures. There was no significant difference in the four digestive enzymatic activities among 30, 33, and $36^{\circ} \mathrm{C}$ treatments $(\mathrm{p}>0.05)$

Table 6. Amylase, trypsin, chymotrypsin and pepsin activities of striped snakehead after rearing 90 days under different temperatures

\begin{tabular}{lrrrr}
\hline Treatment & $\begin{array}{r}\text { Amylase } \\
(\mathbf{U} / \mathbf{m i n} / \mathbf{m g} \text { protein) }\end{array}$ & $\begin{array}{r}\text { Trypsin } \\
(\mathbf{m U} / \mathbf{m i n} / \mathbf{m g} \text { protein) }\end{array}$ & $\begin{array}{r}\text { Chymotrypsin } \\
(\mathbf{U} / \mathbf{m i n} / \mathbf{m g} \text { protein) }\end{array}$ & $\begin{array}{r}\text { Pepsin } \\
(\mathbf{U} / \mathbf{m i n} / \mathbf{m g} \text { protein) }\end{array}$ \\
\hline $24^{\circ} \mathrm{C}$ & $2.20 \pm 0.45^{\mathrm{a}}$ & $2.19 \pm 0.43^{\mathrm{a}}$ & $61.5 \pm 8.69^{\mathrm{a}}$ & $0.28 \pm 0.09^{\mathrm{a}}$ \\
$27^{\circ} \mathrm{C}$ & $2.79 \pm 0.44^{\mathrm{ab}}$ & $2.93 \pm 0.59^{\mathrm{ab}}$ & $75.7 \pm 11.5^{\mathrm{b}}$ & $0.40 \pm 0.08^{\mathrm{a}}$ \\
$30^{\circ} \mathrm{C}$ & $3.30 \pm 0.64^{\mathrm{bc}}$ & $4.20 \pm 0.07^{\mathrm{b}}$ & $95.0 \pm 12.1^{\mathrm{b}}$ & $0.65 \pm 0.22^{\mathrm{b}}$ \\
$33^{\circ} \mathrm{C}$ & $3.82 \pm 0.69^{\mathrm{bc}}$ & $3.44 \pm 0.65^{\mathrm{ab}}$ & $95.0 \pm 12.9^{\mathrm{b}}$ & $0.43 \pm 0.07^{\mathrm{ab}}$ \\
$36^{\circ} \mathrm{C}$ & $4.55 \pm 1.33^{\mathrm{c}}$ & $4.07 \pm 1.26^{\mathrm{b}}$ & $81.7 \pm 9.30^{\mathrm{ab}}$ & $0.46 \pm 0.04^{\mathrm{ab}}$ \\
\hline
\end{tabular}

Data presented as mean \pm std. Values with different letters in the same column is significantly different $(p<0.05)$.

\section{e. Growth performance}

There were significant differences in the weight of fish after 30 and 60 days of culture. The $24^{\circ} \mathrm{C}$ treatment showed the lowest weight at these sampling times $(0.11 \pm 0.02$ and $0.52 \pm 0.16 \mathrm{~g} /$ ind., respectively) and the highest weight of fish was found at $30^{\circ} \mathrm{C}(0.20 \pm 0.04$ and $4.90 \pm 2.12 \mathrm{~g} /$ ind., respectively). After 90 days, fish showed the greater capacity to grow at 27,30 , and $33^{\circ} \mathrm{C}$, which was significantly higher than those in 24 and $36^{\circ} \mathrm{C}$. The highest weight of fish was found at $30^{\circ} \mathrm{C}(13.1 \pm 3.12$ $\mathrm{g}$ /ind.), but there was no significant difference compared to weight of fish reared at 27,30 , and $33^{\circ} \mathrm{C}$. The study indicated that the temperature dropped to $24^{\circ} \mathrm{C}$ or increased up to $36^{\circ} \mathrm{C}$, the growth performance of fish were very low (Fig. 1). 


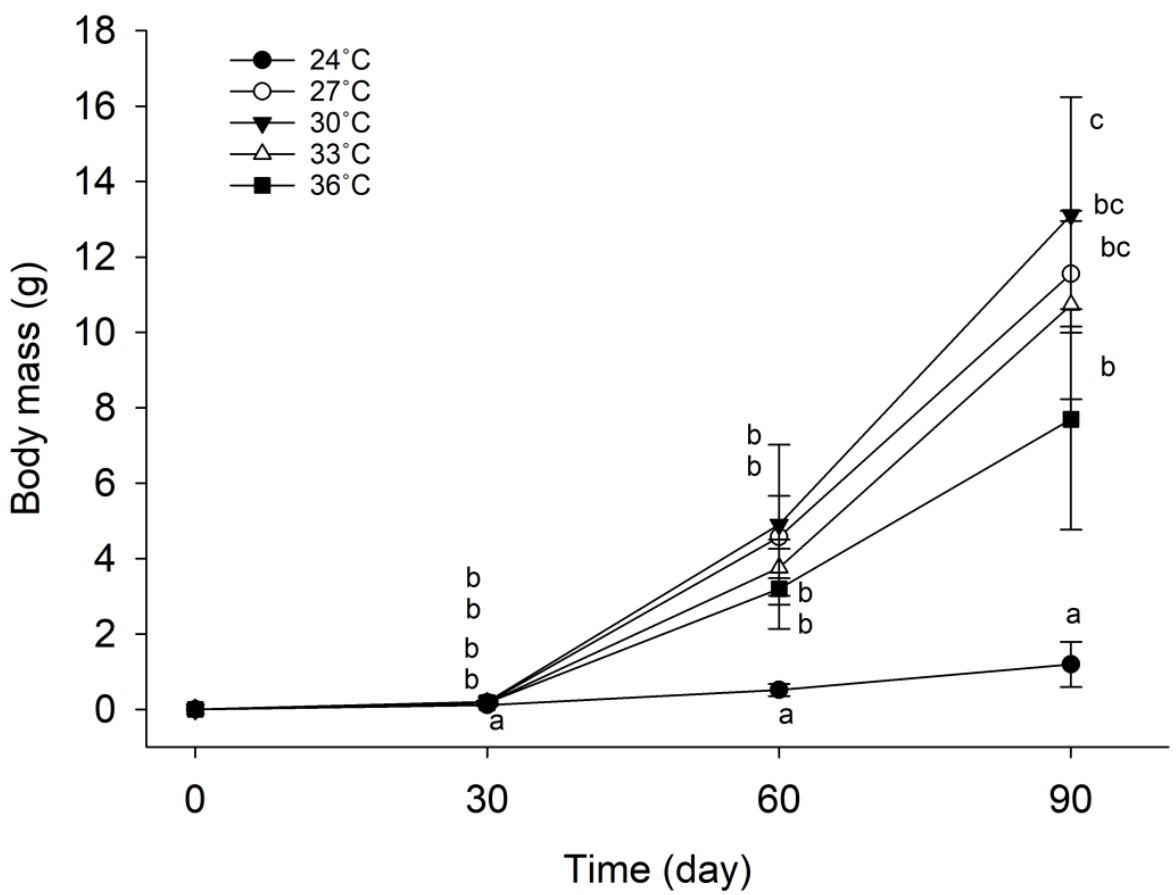

Fig. 1. The body mass of snakehead under different temperatures

Data shown in mean $\pm S D$. The same letter $(a, b, c)$ in the same line were not significantly different $(p>0.05)$

The specific growth rate (SGR) and daily weight gain (DWG) of snakehead after rearing 90 days were highest in the $30^{\circ} \mathrm{C}$ treatment $(7.34 \pm 0.23$ $\% /$ day and $0.14 \pm 0.03 \mathrm{~g} /$ day, respectively), while the lowest values were recorded at the $24^{\circ} \mathrm{C}$ treatment $(5.13 \pm 0.42 \% /$ day and $0.01 \pm 0.006$, respectively). The results show that the growth of fish increases in a range from $24^{\circ} \mathrm{C}$ to $33^{\circ} \mathrm{C}$ and decreased as the temperature exceeds $30^{\circ} \mathrm{C}$ (Table 7).

Table 7. Specific growth rate (SGR) and daily weight gain (DWG) of fish reared at different temperatures for 90 days

\begin{tabular}{lrr}
\hline Treatment & SGR (\%/day) & \multicolumn{1}{c}{ DWG (g/day) } \\
\hline $24^{\circ} \mathrm{C}$ & $5.13 \pm 0.42^{\mathrm{a}}$ & $0.01 \pm 0.006^{\mathrm{a}}$ \\
$27^{\circ} \mathrm{C}$ & $7.24 \pm 0.11^{\mathrm{b}}$ & $0.13 \pm 0.02^{\mathrm{bc}}$ \\
$30^{\circ} \mathrm{C}$ & $7.34 \pm 0.23^{\mathrm{b}}$ & $0.14 \pm 0.03^{\mathrm{c}}$ \\
$33^{\circ} \mathrm{C}$ & $7.16 \pm 0.22^{\mathrm{b}}$ & $0.12 \pm 0.03^{\mathrm{bc}}$ \\
$36^{\circ} \mathrm{C}$ & $6.83 \pm 0.37^{\mathrm{b}}$ & $0.08 \pm 0.05^{\mathrm{b}}$ \\
\hline
\end{tabular}

Data are presented as mean \pm std. Values with different letters in the same column is significantly different $(p<0.05)$.

\section{f. Survival rate}

The survival rate of fish gradually decreased throughout the sampling times. At day 30, the survival rate of fish was not significantly different among treatments $(\mathrm{p}>0.05)$ that ranged between 36.9 and $49.4 \%$. However, the survival rate of fish continued to decrease, at the day $90^{\text {th }}$, the higest survival rate was in $30^{\circ} \mathrm{C}$ treatment $(15.5 \%)$, which was not significantly different in the treatment of 33 and $36^{\circ} \mathrm{C}$ (p>0.05) (Fig. 2).

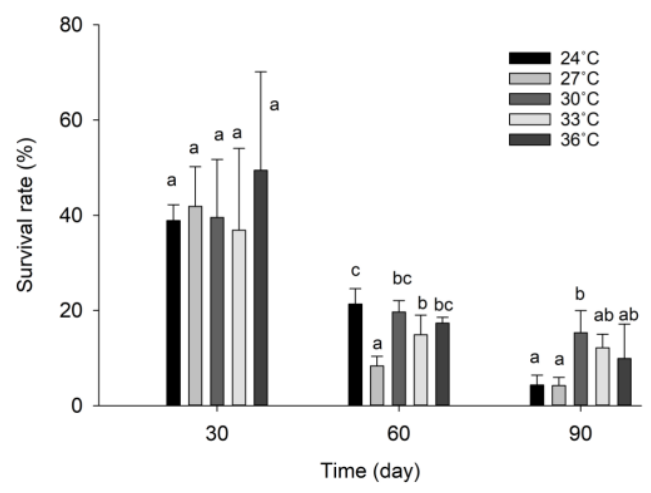

Fig. 2. Survival rate of fish reared at different temperatures

Data shown in mean $\pm S D$. The column with the same letter $(a, b, c)$ in figure were not significantly different $(p>0.05)$ 


\section{DISCUSSION}

\subsection{Temperature threshold}

The temperature threshold range of striped snakehead fry was quite wide. This species was able to tolerate temperature of $10-40^{\circ} \mathrm{C}$. This finding is similar to the paper by Lee and $\mathrm{Ng}$ (1994). Sarma et al. (2010) reported that the critical thermal maxima (CTmax) and minima (CTmin) of Climbing perch (Anabas testudineus) fingerling (17.03 $\pm 1.2 \mathrm{~g})$ after acclimating to three preset temperatures $(25,30$, and $35^{\circ} \mathrm{C}$ ) were $40.15,41.40,41.88^{\circ} \mathrm{C}$ and $12.43,13.06$, $13.94^{\circ} \mathrm{C}$, respectively. Thermal tolerance Ctmax and CTmin of Pangasius pangasius fingerling after acclimating at 30,34 and $38{ }^{\circ} \mathrm{C}$ were $42.68,43.67$, 44.05 and $12.37,14.48,17.22$, respectively (Debnath et al. 2006).

\subsection{Hematological parameters}

In this study, the number of RBCs increased with rising temperature. The increase in the number of RBCs showed a response for the rising demand for oxygen consumption resulted from increasing metabolism and osmoregulation (Martinez-Alvarez et al., 2002). Huong and Tu (2010) stated that RBCs play a vital role in oxygen transfer, and fish exposed to rising temperatures become more active and metabolic, leading to an increase in oxygen demand thereby increase of RBCs. Increased RBCs and $\mathrm{Hb}$ are also common responses dealing with stress (Carvalho \& Fernandes, 2006). The result of this study is in agreement with the study by Hao (2015) on giant gourami (Osphronemus goramy) juveniles, which suggested that the RBCs increased with elevated temperatures from $22^{\circ} \mathrm{C}$ to $34^{\circ} \mathrm{C}$. Similarly, the hematological parameters in eel including RBCs and $\mathrm{Hb}$ tended to increase at high temperatures (Thinh, 2019). A study on Chitala ornata also showed that RBCs also increased when the temperature rose from 27 to $34^{\circ} \mathrm{C}$ (Gam, 2018). Fish cultured in unfavorable conditions, WBCs play a role to protect the fish from pathogen infection (Heath, 1995; Huong \& Tu, 2010). In the current study, WBCs of Channa striata tended to increase when the temperature increased up to $36^{\circ} \mathrm{C}$ although there was no significant difference among treatments ( $>0.05)$. Nhu (2010) reported that WBCs of striped catfish (Pangasianodon hypophthalmus) increased with temperature from $28^{\circ} \mathrm{C}$ to $42^{\circ} \mathrm{C}$.

\subsection{Glucose, cortisol and $\mathrm{Na}^{+}, \mathrm{Cl}^{-}$concentration}

In addition to hematological parameters, plasma glucose and cortisol levels are also useful indicators to assess the capacity of fish to perform under temperature change or other stresses (Boyd \& Tucker, 1998; Pacheco \& Santos, 2001). This study indicated that the plasma glucose and cortisol significantly increased in fish reared at $36^{\circ} \mathrm{C}$ compared to the control treatment. Rising temperatures have been reported to resulted in the increases in cortisol and glucose levels of striped catfish (Thinh et al., 2013), giant gourami (Hao, 2015), and basa catfish (Ha et al., 2017). Kiilerich and Prunet (2011) reported that the cortisol concentration in blood of healthy fish ranged from 5 to $10 \mathrm{ng} / \mathrm{mL}$ and increased up to 10-100 times when fish got stressful. In fresh water teleost, the plasma $\mathrm{Na}^{+}$and $\mathrm{Cl}^{-}$often decreased at low temperature. The explaination for this could be a reduced ability to osmoregulate in the lower temperature (Umminger, 1969). This also could be the decrease in the metabolic cost of osmoregulation when metabolism is reduced (Prosser et al., 1970). According to Houston (1968), $\mathrm{Na}^{+}$and $\mathrm{Cl}^{-}$in freshwater fish usually either rise with increasing temperature or are little affected, and other patterns of variation do also occur. However, in the present study these parameters were not significantly different among temperatures in ranges 24 to $36^{\circ} \mathrm{C}$. These finding are similar in goldfish that the plasma $\mathrm{Na}^{+}$and $\mathrm{Cl}^{-}$was constant in fish acclimated to temperatures between 10 and $30^{\circ} \mathrm{C}$ (Mackay, 1974).

\subsection{Growth and survival rate}

Growth is a specific physiological function and also a continuous process which depends on several factors (Bœuf \& Payan, 2001) such as light (Bœuf \& Le Bail, 1999), temperature (Carriquiriborde et al., 2009), salinity (Peters \& Boyd, 1972; Peterson et al., 1999; Tipsmark et al., 2004; Phuc et al., 2014) and the interaction of temperature and salinity (Phuc, 2015). In this study, within the temperature range from 27 to $33^{\circ} \mathrm{C}$, fish performed a higher growth rate, compared to 24 and $36^{\circ} \mathrm{C}$. This indicates that both increase and decrease in temperature could have impact on the growth performance of snakehead fry. The fish growth performance of the present study is in accordance with findings by Andrews and Stickney (1972); Cox and Coutant (1981); Cuenco et al. (1985) and Requena et al. (1997). The relationship between temperature and growth was also illustrated in a trial carried out by Buentello et al. (2000), in which weight gain was greatest for channel catfish (Ictalurus punctatus) juveniles held at $3^{\circ} \mathrm{C}$ above mean water temperature. Britz and Hecht (1987) reported that Clarias gariepinus performed a higher growth rate at temperatures from 25 to $33^{\circ} \mathrm{C}$, with the highest being shown at $33^{\circ} \mathrm{C}$. This 
confirms the studies which the growth of fish increased with raised temperatures (Hao, 2015; Thinh, 2013; Chinh, 2014). The explanation for this could be that increasing temperature within the thermal tolerance range of the fish results in increases in metabolic processes, enzymatic activity levels, appetite, and foraging efficiency, and thus, in biochemical reaction rates (Brett \& Groves, 1979; Cossins \& Bowler, 1987; Taylor et al., 1997; Huong \& $\mathrm{Tu}, 2010$; Biro et al., 2010). However, the growth of fish dramatically dropped at $36^{\circ} \mathrm{C}$ since at this temperature, fish use much more energy for their increasing metabolic processes and swimming activity. It was revealed that the food consumption of magur (Clarias batrachus) was seen to decrease once the optimal temperature exceeds (Ahmad et al., 2014). The other study on magur also showed that this species grew well up to $32^{\circ} \mathrm{C}$ and were under stress at $35^{\circ} \mathrm{C}$ with mortality being started at $38^{\circ} \mathrm{C}$ (Dehadrai et al., 1985). This has been confirmed by the results of the current study, in which glucose and cortisol significantly increased at $36^{\circ} \mathrm{C}$ and the energy was possibly dedicated to stress responses. Besides, the activities of trypsin and chymotripsin decreased at $36^{\circ} \mathrm{C}$, which could result in a decrease in the growth rate of fish.

On the other hand, low temperature $\left(24^{\circ} \mathrm{C}\right)$ seems to be a stressful condition for fish. Due to feeding behavior that snakehead fry mostly use Moina and powder feed in most of the experimental period, therefore, the data of feed consumption rate could not be achieved in this study. However, common observations suggested that fish might have less appetite for feed at this temperature, resulting in a decrease in the growth rate. Goolish and Adelman (1984) stated that the feed conversion efficiency of common carp (Cyprinus carpio) decreased with lower temperatures. The same result was found by Ahmad et al. (2014), in which the rate of food consumption gradually fell as the temperature decreased from $25^{\circ} \mathrm{C}$ to $10^{\circ} \mathrm{C}$. The survival rate of striped snakehead fry in this study was decreased at low temperature $\left(24^{\circ} \mathrm{C}\right)$. During the experiment, the fish in this treatment showed a low appetite and less active. The enzymatic activities were also low at the treatment of $24^{\circ} \mathrm{C}$, resulting in the decrease in food digestion and absortion which finally caused higher motality rate.

The findings of this study indicated that the growth of fish was greater in a range from $27^{\circ} \mathrm{C}$ to $33^{\circ} \mathrm{C}$. However, $30^{\circ} \mathrm{C}$ could be considered as the optimal temperature for striped snakehead nursing, in which fish showed high growth performance, survival rate, and digestive enzymatic activities with no significant difference in hematological parameters of fish reared at $27^{\circ} \mathrm{C}$ (normal temperature). The fish growth was increased in the range $27-33^{\circ} \mathrm{C}$, and it was reduced as temperature exceeds this range. Therefore, it could be assumed that striped snakehead can tolerate with global warming situation predicted by IPCC (2014).

\section{CONCLUSIONS}

Striped snakehead at fry stage showed a high tolerance to temperatures ranging from 10 to $40^{\circ} \mathrm{C}$. At the temperatures approaching the upper limitation level, the hematological parametter tended to increase as a response for the temperature stressor. The optimal temperature for striped snakehead nursing could be $30^{\circ} \mathrm{C}$ that the fish show better growth and survival. Snakehead fry development was dramatically impacted as temperature significantly dropped reaching $24^{\circ} \mathrm{C}$ or increased up to $36^{\circ} \mathrm{C}$.

\section{ACKNOWLEDGMENT}

This study was funded in part by the Can Tho University Improvement Project VN14-P6 supported by a Japanese ODA loan.

\section{REFERENCES}

Ahmad, T., Singh, S. P., Khangembam, B. K., Sharma, J. G. \& Chakrabarti, R. (2014). Food consumption and digestive enzyme activity of Clarias batrachus exposed to various temperatures. Aquaculture Nutrition, 20(3), 265-272.

Andrews, J. W. \& Stickney, R. R. (1972). Interactions of feeding rates and environmental temperature on growth, food conversion, and body composition of channel catfish. Transactions of the American Fisheries Society, 101(1), 94-99.

Bernfeld, P. (1951). Enzymes of starch degradation and synthesis. In. F. F. Nord (Eds.), Advances in enzymology and related areas of molecular biology (pp. 379-428). Interscience Publishers, Inc. Doi: 10.1002/9780470122570.ch7

Bhikajee, M., \& Gobin, P. (1998). Effect of temperature on the feeding rate and growth of a red tilapia hybrid. Tilapia Aquaculture. Proceedings from the 4th International Symposium on Tilapia Aquaculture, 1, 131-140.

Biro, P. A., Beckmann, C., \& Stamps, J. A. (2010). Small within-day increases in temperature affects boldness and alters personality in coral reef fish. Proceedings of the Royal Society B: Biological Sciences, 277(1678), 71-77.

Bœuf, G., \& Payan, P. (2001). How should salinity influence fish growth?. Comparative Biochemistry and 
Physiology Part C: Toxicology \& Pharmacology, 130(4), 411-423.

Bœuf, G., Boujard, D. \& Person-le Ruyet, J. (1999). Control of the somatic growth in turbot. Journal of Fish Biology, 55, 128147.

Boyd, C. E., \& Tucker, C. S. (1998). Pond aquaculture water quality management. Springer Science \& Business Media, LLC.

Boyd, C. E. (1990). Water quality in ponds for aquaculture. Alabama Agricultural Experiment Station, Auburn university. Alabama.

Brett, J. R. (1979). Environmental factors and growth. In: Hoar, W. S., Randall, D. J., Brett, J. R. Eds. Fish Physiology, 8, 599-675.

Brett, J. R. \& Groves, T. D. D. (1979). Physiological energetics. Fish physiology, 8(6), 280-352.

Britz, P. J. \& Hecht, T. (1987). Temperature preferences and optimum temperature for growth of African sharptooth catfish (Clarias gariepinus) larvae and postlarvae. Aquaculture, 63(1-4), 205-214.

Buentello, J. A., Gatlin III, D. M. \& Neill, W. H. (2000). Effects of water temperature and dissolved oxygen on daily feed consumption, feed utilization and growth of channel catfish (Ictalurus punctatus). Aquaculture, 182(3-4), 339-352.

Carriquiriborde, P., Díaz, J., López, G. C., Ronco, A. E. \& Somoza, G. M. (2009). Effects of

cypermethrin chronic exposure and water temperature on survival, growth, sex

differentiation, and gonadal developmental stages of Odontesthes bonariensis (Teleostei). Chemosphere, 76, 374-380.

Carvalho, C. S. \& Fernandes, M. N. (2006). Effect of temperature on copper toxicity and hematological responses in the neotropical fish Prochilodus scrofa at low and high pH. Aquaculture, 251(1), 109-117.

Chinh, V.T. (2014). Effect of temperature on digestive enzyme activity, ingestion and growth performance of striped snakehead (Channa striata Bloch, 1793) (master's thesis). Can Tho University, Can Tho city, Vietnam (in Vietnamese).

Cossins, A. R. \& Bowler, K. (1987). Temperature Biology of Animals ( $1^{\text {st }} \mathrm{ed}$.). Chapman \& Hall, London. Doi: 10.1007/978-94-009-3127-5.

Cox, D. K. \& Coutant, C. C. (1981). Growth dynamics of juvenile striped bass as functions of temperature and ration. Transactions of the American Fisheries Society, 110(2), 226-238.

Cuenco, M. L., Stickney, R. R. \& Grant, W. E. (1985). Fish bioenergetics and growth in aquaculture ponds: II. Effects of interactions among, size, temperature, dissolved oxygen, unionized ammonia and food on growth of individual fish. Ecological modeling, 27(3-4), 191-206.

Debnath, D., Pal, A. K., Sahu, N. P., Baruah, K., Yengkokpam, S., D., T. \& Manush, S. M. (2006). Thermal tolerance and metabolic activity of yellowtail catfish Pangasius pangasius (Hamilton) advanced fingerlings with emphasis on their culture potential. Aquaculture, 258(1-4), 606-610.

Dehadrai, P. V., Yusuf, K. M. \& Das, R. K. (1985). Package of practices for increasing production of air breathing fishes. Aquaculture extension manual, 3 , $1-14$.

Dutta, H. (1994). Growth in Fishes. Gerontology, 40(24), 97-112.

Elliott, J. M. (1982). The effects of temperature and ration size on the growth and energetics of salmonids in captivity. Comparative Biochemistry and Physiology, 73B, 81-91.

Gam, L. T. H. (2018). Effects of nitrite, temperature and hypercapnia on physiological processes and growth in clown knifefish (Chitala ornata, Gray 1831) (Doctoral dissertation). Can Tho University.

Gasparrini, A., Guo, Y., Sera, F., Vicedo-Cabrera, A. M., Huber, V., Tong, S., ... \& Armstrong, B. (2017). Projections of temperature-related excess mortality under climate change scenarios. The Lancet Planetary Health, 1(9), e360-e367. doi.org/10.1016/S25425196(17)30156-0

Goolish, E. M. \& Adelman, I. R. (1984). Effects of ration size and temperature on the growth of juvenile common carp (Cyprinus carpio L.). Aquaculture, 36(1-2), 27-35.

Ha, N .T. K., Bieu, N. T. X., Phuong, N. T., \& Huong, D. T. T. (2017). Effect of $\mathrm{CO}_{2}$ on acid-base regulation and growth performance of basa catfish (Pangasius bocourti). Can Tho University Journal of Science, 54(2), 18-26.

Hao, V. Q. (2015). The effects of temperature on physiological parameters and growth rate of giant gourami (Osphronemus goramy) juveniles (master's thesis). Can Tho University (in Vietnamese).

Heath, A. G. (1995). Water Pollution and Fish Physiology. Second edition. CRC Press, Inc.

Houston, A. H., Reavds, R. S., Madden, J. A. \& DeWilde, M. A., (1968). Environmental temperature and the body fluid system of the fresh-water teleostI. Ionic regulation in thermally acclimated rainbow trout, Salmo gairdneri. Comparative Biochemistry and Physiology, 25, 563-581.

Hrubec, T. C., Cardinale, J. L. \& Smith, S. A. (2000). Hematology and plasma chemistry reference intervals for cultured tilapia (Oreochromis hybrid). Veterinary clinical pathology, 29(1), 7-12.

Hugget, A. S. G. \& Nixon, D. A. (1957). Use of glucose oxidase, peroxidase and o-dianisidine in determination of blood and urinary glucose. The Lancet, 270 (6991), 368-370.

Huong, D. T. T., Ky, T. M., Ha, N. T. K., Em, N. T., Takagi, Y. \& Phuong, N. T. (2020). Effects of salinity on physiological parameters, digestive enzyme 
activities and growth of snakehead fish (Channa striata). Can Tho University Journal of Science. Special issue on Aquaculture and Fisheries, 56(1), 11-19 (in Vietnamese).

Huong. D.T.T. \& Tu, N.V. (2010). Introduction to the physiology and fish and crustacean. Agricultural Publishing House. Ho Chi Minh City. 152 pages (in Vietnamese).

IPCC. (2007). Summary for policymakers. Climate change 2007: The physical science basis. In Contribution of Working Group I to the Fourth Assessment Report of the Intergovernmental Panel on Climate Change (pp. 1-13). Cambridge University Press Cambridge, UK.

IPCC, (2014). Climate change 2014: synthesis report. Contribution of Working Groups I, II and III to the fifth assessment report of the Intergovernmental Panel on Climate Change. 151 pages.

IPCC. (2018). Global warming of $1,5^{\circ} \mathrm{C}$. Summary for Policymakers. 26 pages.

Kiilerich, P. \& Prunet, P. (2011). Hormonal control of metabolism and ionic regulation Corticosteroids. In: Farrell A.P. (Eds). Encyclopedia of Fish Physiology. Academic Press. San Diego. 1474-1482.

Lee, P. G. \& Ng, P. K. (1994). The systematics and ecology of snakeheads (Pisces: Channidae) in Peninsular Malaysia and Singapore. In Ecology and Conservation of Southeast Asian Marine and Freshwater Environments including Wetlands, 59-74.

Long, D. N., Lan, L. M. \& Tuan, N. A. (2017). Biology and culture technique of freshwater species in $\mathrm{Me}$ kong Delta. Labor publishing house. Ho Chi Minh City (in Vietnamese).

Mackay, W. C. (1974). Effect of temperature on osmotic and ionic regulation in goldfish, Carassius auratus L. Journal of comparative physiology, 88(1), 1-19.

Martinez-Alvarez, R. M., Hidalgo, M. C., Domezain, A., Morales, A. E., García-Gallego, M. \& Sanz, A. (2002). Physiological changes of sturgeon Acipenser naccarii caused by increasing environmental salinity. Journal of experimental biology, 205(23), 3699-3706.

Natt, M. P. \& Herrick, C. A. (1952). A new blood diluent for counting the erythrocytes and leucocytes of the chicken. Poultry Science, 31, 735-738.

Nhu, T.T.B. (2010). Effects of Malachitegreen and temperature on physiological parameters and Cholinesterase of striped catfish (Pangasianodon hypophthalmus) (master's thesis). Can Tho University, Can Tho city, Vietnam (in Vietnamese).

Hawk, B.P. (1965). Blood analysis. Estimation of Hb by cyanomethemoglobin method, In B. L. Oser (Eds.), Hawk's Physiological Chemistry (pp. 1096). The Blackston Division McGraw-Hill Book Company.

Pacheco, M., \& Santos, M. A. (2001). Biotransformation, endocrine, and genetic responses of Anguilla anguilla $\mathrm{L}$. to petroleum distillate products and environmentally contaminated waters. Ecotoxicology and Environmental Safety, 49(1), 64-75.

Peters, D. S. \& Boyd, M. T. (1972). The effect of temperature, salinity, and availability of food on the feeding and growth of the hogchoker, Trinectes maculatus (Bloch and Schneider). Journal of Experimental Marine Biology and Ecology, 9(2), 201-207.

Peterson, M. S., Comyns, B. H., Rakocinski, C. F. \& Fulling, G. L. (1999). Does salinity affect somatic growth in early juvenile Atlantic croaker, Micropogonias undulatus (L.)?. Journal of Experimental Marine Biology and Ecology, 238(2), 199-207.

Phuc, N. T .H. (2015). Effects of temperature and salinity on growth performance in cultured tra catfish (Pangasianodon hypophthalmus) in Vietnam $(\mathrm{PhD}$ dissertation). Queensland University of Technology Brisbane, Australia.

Phuc, N. T. H., Huong, D. T. T., Mather, P. B. \& Hurwood, D. A. (2014). Experimental assessment of the effects of sublethal salinities on growth performance and stress in cultured tra catfish (Pangasianodon hypophthalmus). Fish physiology and biochemistry, 40(6), 1839-1848.

Prosser, C. L., Mackay, W. \& Kato, K. (1970). Osmotic and ionic concentrations in some Alaskan fish and goldfish from different temperatures. Physiological Zoolozy, 43, 81-89.

Requena, A., Fernandez-Borras, J. \& Planas, J. (1997). The effects of a temperature rise on oxygen consumption and energy budget in gilthead sea bream. Aquaculture International, 5(5), 415-426.

Sarma, K., Pal, A. K., Ayyappan, S., Das, T., Manush, S. M., Debnath, D. \& Baruah, K. (2010). Acclimation of Anabas testudineus (Bloch) to three test temperatures influences thermal tolerance and oxygen consumption. Fish physiology and biochemistry, 36(1), 85-90.

Seggel, A. \& De Young, C. (2016). Climate change implications for fisheries and aquaculture: summary of the findings of the Intergovernmental Panel on Climate Change Fifth Assessment Report. FAO Fisheries and Aquaculture Circular. C1122.

Snellgrove, D. L. \& Alexander, L. G. (2011). Haematology and plasma chemistry of the red top ice blue mibuna cichlid (Metriaclima greshakei). British Journal of Nutrition, 106, 154-S157.

Talwar, P. K., \& Jhingran, A. G. (1991). Inland fishes of India and adjacent countries, volume two. Oxford IBH Publishing Co Pvt Ltd, New Delhi-Calcutta. 543-1158.

Taylor, E. W., Egginton, S., Taylor, S. E. \& Butler, P. J. (1997). Factors which may limit swimming performance at different temperatures. In Seminar seriessociety for experimental biology, 61, 105-134.

Thinh, P. V. (2019). Effects of $\mathrm{CO}_{2}$, temperature and nitrite on acid-base regulation and haematological 
parameters in Swamp eels (Monopterus albus Zuiew, 1793) (Doctoral dissertation). Can Tho University, Can Tho city, Vietnam.

Thinh, P. V., Phuong, N. T., Huong, D. T. T \& Phuc, N. T. H. (2013). The effects of temperature on physiological parameters and growth rate of catfish (Pangasianodon hypophthalmus). Can Tho University Journal of Science. Special issue on Aquaculture and Fisheries, (1), 292-301 (in Vietnamese).

Tipsmark, C. K., Madsen, S. S. \& Borski, R. J. (2004). Effect of salinity on expression of branchial ion transporters in striped bass (Morone saxatilis). Journal of Experimental Zoology Part A: Comparative Experimental Biology, 301, 979-991.
Tseng, H. C., Grendell, J. H. \& Rothman, S. S. (1982). Food, duodenal extracts, and enzyme secretion by the pancreas. American Journal of Physiology, 243, 304-312.

Umminger, B. L. (1969). Physiological studies on supercooled killifish (Fundulus heteroclitus) I. Serum inorganic constituents in relation to osmotic and ionic regulation at subzero temperatures. Journal of Experimental Zoology, 172(3), 283-302.

Worthington T. M. (1982). Enzymes and Related Biochemicals. Biochemical Products Division, Worthington Diagnostic System, Freehold, NJ, USA. 